\title{
CONSTRUCTION OF NETWORK ENTREPRENEURIAL PLATFORM LEADERSHIP CHARACTERISTICS MODEL: BASED ON THE GROUNDED THEORY
}

\author{
Jianlin $\mathrm{PAN}^{1^{*}}$, Jie $\mathrm{LIN}^{2}$ \\ ${ }^{1}$ School of Economics and Management, YiWu Industrial \& Commercial College, \\ 322000 Yiwu Zhejiang, China \\ ${ }^{2}$ School of Economics and Management, Zhejiang University of Water Resources \\ and Electric Power, 310018 Hangzhou Zhejiang, China
}

Received 26 September 2018; accepted 27 June 2019

\begin{abstract}
With the embedding of internet technology, the entrepreneurial model has been gradually developing from traditional single linear channel into network platform with symbiotic multi-platform. Platform leadership is the most important part of the new one and has been caught greatest attention. This paper put forward a new conception of network entrepreneurial platform leadership innovatively. By the integrated use of the Classical Grounded theory, the Procedure Grounded Theory and the Construction Grounded Theory, it adopted the normative research process of open coding, axial coding and selective coding to refine 34 concept - multi-node interactive, cross-level coupling relationship, etc, and formed 11 fundamental categories which include platform leadership power, network organization entrepreneurial mode, etc. Then, we analyzed the interactions between categories, based on which, a double-level and three-type-characteristics model were ultimately built. The study was finished by both two methods of statistical software and manual operation. In order to improve the reliability and validity of the study, it invited another coder to test the category subordination collaboratively, and used matched group to test the theoretical saturation.
\end{abstract}

Keywords: platform, platform leadership, network entrepreneurial platform leadership, two-sided market, network organization, The Grounded Theory.

JEL Classification: D21, M13, M21.

\section{Introduction}

With Alibaba successful listing in the United States, the strong vitality of new organizational model for such multilateral network enterprises has been showed up, and the platform has become a new economic growth model. Since the over 10 billion Yuan trade volume of Taobao "Double-11" shopping carnival has strong impact on the traditional market, Jingdong,

*Corresponding author. E-mail: jianlin9@163.com 
the vertical electric business platform in the field of network platform entrepreneurship and Alibaba that started as the lateral electric business platform, has been competing for the top position of electric platform; since the advent of the era of APP and light application, the battle for network payment platform between Alipay and WeChat Payment; since the successful acquisition of WhatsApp in 2014, only ten-year-old Facebook has already implemented its strategy of integrating mobile and physical networking platform in a big way. The abovementioned cases highlight network entrepreneurial platform competition gradually become commonplace in the era of information economy, and it is transforming from a closed system to an open system. Based on such an era of Platform Economics (Akbar \& Tracogna, 2018), platform thinking becomes increasingly important (Langley \& Leyshon, 2017), and becoming the mainstream logic of corporate competitive strategy (Luo \& Du, 2018).

In essence, platform is an embodiment of market, and a network organization posed by node and mutual connection. The node in the platform is the interest related part of the network organization, which is platform-dependent main participant; mutual connection refers to process of each node that based on potential position and interrelation of platforms organization to form characteristics of the network with the contract structure. However, due to differences in position and potential in network organization, which makes the relationship among each main body may presents various relationship status such as paired or binary relationship, organized rings, network among organizations. With the deepening openness and increasing range of platform, the formal or informal structure of the contractual relationship among each main body becomes more complex and dynamic. Driven by interest demands, each main body gets platforms resources in the structural framework of platform through competition, complementary and other synergistic strategies, to achieve synergistic entrepreneurship, and promote prosperity and development of platform. In the relationship, synergy and interactive mode among main bodies, the main body at the heart of platform network organization has a leadership potential throughout the network entrepreneurial platform ecosystem, which is the key to the establishment and development of network entrepreneurial platform. And this leadership potential urges the main body able to achieve leadership role in the network entrepreneurial platform, which has given it the strong powers such as resource allocation, rules definition, benefit distribution, and platform framework design. It is based on the importance of platform leadership as well as the powers it has, in the time of platform entrepreneurship economy, many enterprises and organizations scramble for it. The war of the network entrepreneurial platform leadership is gaining momentum (Cusumano, 2011).

However, the ups and downs in the field of the e-commerce platform and war alarms raised everywhere in the new battlefield of the network financial platform indicate that the network entrepreneurial platform leadership cannot be accomplished overnight, and is not once and for all. Addition to the general characteristics of platform, it also has its own particularity. Although $\mathrm{Xu}$ and other domestic scholars have been studied the basic characteristics of the platform, domestic and foreign researches on concept of and characteristics of platform leadership are rare, let alone the researches on the network entrepreneurial platform leadership which is almost blank. This makes the current entrepreneurial practices of network platform lack of theoretical reference, especially the creation and development of 
the network entrepreneurial platform leadership. It is based on the research background of lacking theoretical literature, this study takes the network entrepreneurial platform leadership as the research object, and uses the grounded theory research method to construct the multidimensional model of the network entrepreneurial platform leadership, and realizes the purpose of expanding the network entrepreneurship theory research and promoting the network entrepreneurship practice.

The rest of the paper is organized as follows. Section 1 describes the literature on platform leadership. Section 2 describes the research method and design. Section 3 proposes the model construction based on the Grounded Theory. In Section 4, we present the research findings. Final section summarizes and concludes the paper.

\section{Literature review}

With the joint promotion of scholars such as Rochet and Tirole (2003), the French Institute of Industrial Economics (IDEI) and Policy Research Center (CEPR) jointly organized the "Two-sided Market Economics" conference in Toulouse, France in 2004. It's the time that research of platform based on two-sided market theory received more attention. The progress of the research on platform contributed to the formation of two perspectives of theoretical frameworks as business perspective and technological perspective (Gawer, 2014). The technology platform of technological perspective as firstly discussed. This perspective focus on technological innovation, and thinks that the value platform derived from providing building blocks for other companies (Gawer \& Henderson, 2007). Otherwise business perspective holds that the platform is not only a technical products platform of the core components and the complementary components, but also a virtual or physical transaction space to promotes transactions of two parties or even multi-parties, which is a broader, more complex and dynamic industry commercial platform (Langley \& Leyshon, 2017). Platform derives value by providing trading information, products, channels, pricing, and other services for two-sided market (McIntyre \& Srinivasan, 2017). But no matter in a business perspective or a technical perspective, the key body of the platform network system is the "platform leadership" (Gawer \& Cusumano, 2007; Sako, 2018) or "keystone firm" (Iansiti \& Levien, 2004).

For this reason, scholars are beginning to pay more attention to the research of platform leadership, among which Gawer and Cusumano are research pioneers in this field. By studying Intel, Microsoft and Cisco and other enterprise organizations, Gawer and Cusumano (2007) for the first time put forward the four decision principles of platform leadership strategy, thus providing a basis for follow-up research platform leadership theory, and research field of platform leadership also thereby get expanded. Fang and Tan (2017) carried out an research on leadership strategy of new industry innovation platform based on evolutionary game. Luo and Du (2018) conducted a research of real options in platform leadership. Rietveld and Eggers (2018) explored how the evolution of a platform's user base from one dominated by early adopters to one dominated by late adopters affect performance outcomes for complementary products. Tura, Kutvonen, and Ritala (2018) developed a framework for platform design, involving four elements: 1) platform architecture, 2) value creation logic, 3) governance, and 4) platform competition. 
Throughout the existing research results, although the integration of business and technological perspective catches greater attention to, the platform leadership research is still focused on the field of technical platform leadership. Its research contents and methods tend to be a single case description, and lacks of theoretical induction and analysis. Such as the study on Intel platform leadership position maintenance carried out by Perrons (2009), success factors analysis on web 2.0 platform leadership carried out by S. M. Lee, Kim, Noh, and B. Lee (2010), and prosperity and decline reason analysis on Symbian Systems Inc. carried out by West and Wood (2011), they all belong to the single-case descriptive studies of technical platform. Despite all this, by retrieving, analyzing and integrating these scattered existing theoretical literature, the researchers preliminarily got two basic characteristics of platform leadership: one is industry-oriented, that is platform leadership is focusing on the goal of innovation and development in its industry; the other one is significant network effects (direct or indirect effects of external and internal), so that provides certain theoretical basis for this study. However, it is undeniable that some scholars have realized this problem and focused on analyzing platform leadership from a commercial perspective. For example, Nambisan, Siegel, and Kenney (2018) brought a sharper focus on the important research issues and questions that frame open innovation, platforms and entrepreneurship. Täuscher and Laudien (2018) provided a conceptually and empirically grounded taxonomy of platform business models. These studies also provide reasonableness for this article.

\section{Research method and design}

\subsection{Research method}

Grounded Theory is a qualitative research method proposed by the American sociologist Glaser and Strauss in 1967 (Timonen, Foley, \& Conlon, 2018). It was created for "fill the awkward gap between theoretical research and empirical research" (Glaer, Strauss, \& Strutzel, 1968). Its core idea is emphasis on the proposition of research issue and the formation of theory are all natural emergence processes (Wiesche, Jurisch, Yetton, \& Krcmar, 2017), and it is a typical effective method that establishes the theory (Rieger, 2019) through a qualitative method. The unique research methodology and scientific grounded spirit of Grounded Theory have been gradually applied and spread. The US AMJ believe that articles adopt Grounded method are the most interesting researches (Bartunek, Rynes, \& Ireland, 2006), and their reference rate is also very frequent (Aldiabat $\&$ Navenec, 2018). This is an effective method to construct theory in the shortage areas of theory and literature, and particularly suitable for the establishment of a new theory in China. Because of serious lacking of the theoretical research of network entrepreneurial platform leadership, it is more appropriate to use Grounded Theory to construct a new theory.

In the development process of Grounded Theory, there gradually formed Glaser and Strauss's classic grounded theory, Strauss and Corbin's procedural grounded theory, and Charmin's constructive grounded theory the three schools (Jia \& Tan, 2010). Based on the above three theoretical schools, this study will use semi-structured interview in data collection, and follow the classical grounded theory to avoid researcher's subjective impact as 


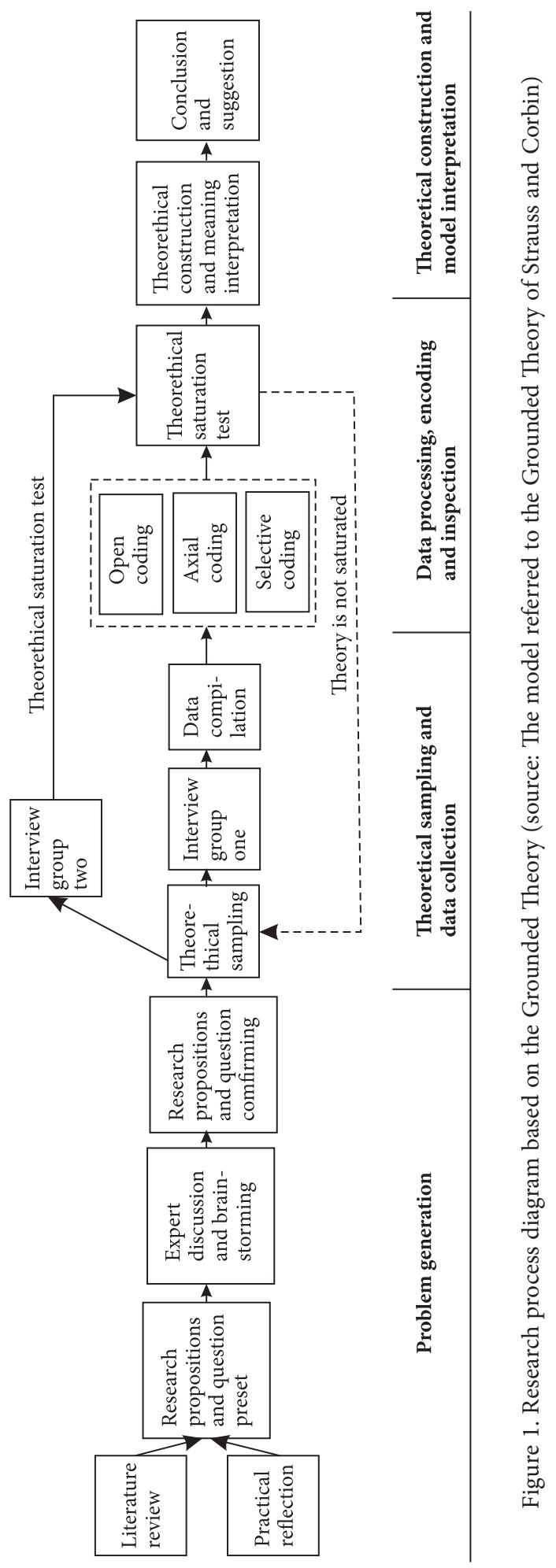


much as possible during the interview; follow the procedural grounded theory to improve the operability of study throughout the study design; follow constructive grounded theory to increase the saturation of theory construction in the process of theoretical induction and deduction, and make explanation about the model. Based on the above discussions, the basic process of this study can be divided into four stages; The details are shown in Figure 1.

\subsection{Theoretical sampling}

Based on the two-sidedmarket theory, Parker and Van Alstyne (2012) considered the platform as four elements of the platform sponsor, platform provider users, users demand side, and users supply side. Van Alstyne, Parker, and Choudary (2016) put forward a new foursubject containing platform providers, platform owner, producers and consumers. According to Gawer (2014), the four-subject taxonomy sees platform as two-sided market on the business perspective. In addition to be viewed as a two-sided market, the platform can also be regarded as technological architectures on the technological perspective. From technological perspective, the platform realizes the collaborative development of platform leadership and complementary developers through open interfaces, and thus forms an "innovation ecosystem" (Adner \& Kapoor, 2010; Nambisan \& Sawhney, 2011) or "ecologies of complex innovation" (Dougherty \& Dunne, 2011) with platform leadership as the core and enterprise or individual innovation developers as members. Based on the above theory, this paper adopts Gawer's integrative framework theory (Gawer, 2014), which regards platform developed users (enterprise or individual developers) as the components of the platform, and merges producers and consumers into two-sided market users. Based on this, the research proposed platform should include platform leadership main creator, platform leadership, two-sided market user, and platform developed user. In this platform framework, except platform leadership is impersonal main body, the other three main bodies can act as interview subjects. In addition, researcher of platform leadership filed is also an indispensable platform interview subject. From the number of interview samples, mature experience of grounded theory believes samples are preferably among 20-30 (Fassinger, 2005). Based on the above discussion, this study determined four types of groups as the source of sample collection which were the platform leadership creator, platform two-sided market user, platform developed user, and platform researcher.

Meanwhile, considering that around 50\% samples will be used for theoretical saturation test, thus this study collected a total of 50 samples to conduct interviews that lasted more than six months, of which 35 samples interviews used face to face communication, and 15 samples used network communication. Interview subjects mainly from Zhejiang and Guangzhou provinces where the network platform entrepreneurship developed vigorously, as well as in Shanghai, Beijing, Jiangsu. Because one of the platform creators is unwilling to continue participating in the survey in the midway, so his interview result is not be regarded as effective interview data. The amount of effective raw data of the study is 49. Its samples composition and number as follows: there are 11 platform leadership creators or participants, involving creators or participants from "Yiwugou", "Wanke mall", "Zhenai business housewares", "Huiqisi department store" and other medium and small wholesale network platforms 
and "Taobao" and other large network trade circle, and those samples are numbered as 1-11; there are 15 platform two-sided market user, including owners with higher reputation for online shop and rich experience of platform operating, 5 platform senior buyers, and those samples are numbered as 12-26; there are 10 platform developed users, such as users who provide application development or management tools for "Yiwugou", "Taobao" and other platforms, and those samples are numbered as 27-36; There are 13 platform specific researchers, including Taobao university lecturer, expert of network platform entrepreneurship guidance from Yiwu Industrial and Commercial College which is honored as "cradle of the world's best network businessman", e-commerce professor, etc., and those samples are numbered as 37-49. After the data collection, the researchers extracted 5 persons from the 11 platform leadership creator or participants (numbered as 2, 4, 6, 8, 10), 8 persons from the platform two-sided market users samples (numbered as 12, 14, 16, 18, 20, 22, 24, 26), 5 persons from the platform developed users samples (numbered as $28,30,32,34,36$ ), and 6 persons from platform researchers samples (numbered as $38,40,42,44,46,48$ ), with a total of 24 samples consist of interview group two, and the data will be used as theory saturation test. Another 25 samples consist of interview group one and the data will be used as model construction.

\subsection{Question design}

The topic of this study is characteristics and structural relationships of network entrepreneurial platform leadership. Based on the study topic, researchers drew up eight initial interview outlines. After the initial interview outlines drew up, researchers invited 5 scholars with a certain platform research interests and experience, to have a brainstorming discussion which lasted up to two hours. Combined with the views of experts and scholars, researchers readjusted interview outlines, and finalized five interview questions: Question 1. What are the general characteristics of platform? Question 2: Compared to platform, what are the characteristics of platform leadership? Question 3: What are the characteristics of network entrepreneurial platform leadership? Question 4: Do you have any special network entrepreneurial platform leadership to recommend? What are the characteristics of them? Question 5: What the core characteristic do you think network entrepreneurial platform leadership is? Among them, Question 1 is intended to analyze the general characteristics of platform; Question 2 is intended to analyze the characteristics of platform leadership; Question 3 is intended to analyze the characteristics of network entrepreneurial platform leadership; Question 4 and 5 are intended to analyze the core characteristics of network entrepreneurial platform leadership, and thus to construct a multi-dimensional characteristic structure model. Climaxtype logical relationship exists among these five questions, so as to facilitate analysis of the subsequent main category relationship. What's more, there is a side comparison relationship between question 4 and 5 , so as to facilitate comparison test interview data. 


\section{Model construction}

\subsection{Open coding}

Open coding is the process that from a series of messy original information such as audio interviewing record doing the job of selecting in repeatability, integrating in similarity and refining in semanteme, finally forming the progressive coding from original statements to conception to category. During the whole process, the research follows the three operational steps of open coding issued by Strass and Corbin. That is, dividing the original statements into several events and doing the according phenomenal excerpt, developing the conception according to the principles like the content of affairs, directing theory category and so on, therefore forming the concept group, i.e. category of more directive property on the basis of concept.

\subsubsection{Extract effective analytic unit (Event)}

Although the original audio interviewing record is kept according to the sequence of 5 questions, the information is still scattered. Therefore, the researchers put the original data attained by the interviewers in order by using the code-analyzing software NVIVO8.0, and it was the first time that they had received 401 free-knots. Later on they selected those data above again, receiving 291 preliminary analytic units. For the convenience of proceeding coding, the researchers do the code conversion to the analytic unites using the coding method of question code, sample code, letter "a" and the serial number of analytic units. For example, the code " $4-13-a 1$ " represents pointing to the $4^{\text {th }}$ question, the original statement of the first effective answer by the $13^{\text {th }}$ interviewee. The following is part of material about the $13^{\text {th }}$ interviewee answering the $4^{\text {th }}$ question, of which the underlying part is the original analytic units of this research:

It has been 3 years since I had an online store on Taobao.com. As far as I am concerned, Taobao.com is not too bad choice of platform, because there are so many registered users, with the number of about 500 million that it offers a great opportunity of a robust market (4-13-a1). Meanwhile, it is very convenient to do business on Taobao.com, because there is a lot of statistical software for direct use, which is convenient not only to manage stores but also for us to have a good understanding of the competitors (4-13-a2). The brand effect of Taobao.com is also very good (4-13-a3). And lots of friends around me visit Taobao.com every day. It is the leader of the online retailer markets in China (4-13-a4), which is why I chose it.

\subsubsection{Refine concept}

After acquiring the 291 original analytic units researchers do the concept refinement, delete 24 less effective analytic units and finally obtaining 267 analytic units and concepts, without taking the repeatability and similarity of concepts refined from different samples into consideration. Because 24 useless analytic units are deleted, the researchers re-code the remaining 267 effective analytic units. The detailed coding course is exemplified in Table 1. 
Table 1. Example of the concept of open encoding (original data are derived from 13th samples' answer to the 4 th question)

\begin{tabular}{|c|l|l|l|}
\hline Code & \multicolumn{1}{|c|}{ The original analysis unit } & Phenomenon summary & \multicolumn{1}{c|}{ Concept } \\
\hline 4-13-a1 & $\begin{array}{l}\text { There are a lot of registered users. Taobao } \\
\text { currently has about 5 million registered } \\
\text { users. There is a huge market opportunity. }\end{array}$ & $\begin{array}{l}\text { Platform has a lot of } \\
\text { users }\end{array}$ & $\begin{array}{l}\text { Platform user } \\
\text { resource }\end{array}$ \\
\hline 4-13-a2 & $\begin{array}{l}\text { Business on Taobao is special convenient. } \\
\text { There are a lot of direct use of statistical } \\
\text { software, which facilitate I shop } \\
\text { management, also easy to me to understand } \\
\text { the competitors situation. }\end{array}$ & $\begin{array}{l}\text { Platform has a lot of } \\
\text { practical technical tools } \\
\text { to share }\end{array}$ & $\begin{array}{l}\text { Platform } \\
\text { technology } \\
\text { support } \\
\text { resources }\end{array}$ \\
\hline 4-13-a3 & Taobao brand effect is also very good. & $\begin{array}{l}\text { Platform has a good } \\
\text { brand }\end{array}$ & Platform brand \\
\hline 4-13-a4 & $\begin{array}{l}\text { It is also the first one of China's online retail } \\
\text { market. }\end{array}$ & $\begin{array}{l}\text { The industry leading } \\
\text { status of the platform }\end{array}$ & Industry status \\
\hline
\end{tabular}

\subsubsection{Formation category}

Based on 267 original concepts, according to the repeatability, similarity and relevancy of the content of concepts refined from different samples, the researchers further conclude those into 34 categories and transform their codes in the form of question "code + aa + serial number". The details are shown in Table 2.

Table 2. Categories which are formed by the open coding

\begin{tabular}{|c|c|c|c|c|c|}
\hline \multicolumn{3}{|c|}{$\begin{array}{l}\text { Question 1: What are the general } \\
\text { characteristics of the platform? }\end{array}$} & \multicolumn{3}{|c|}{$\begin{array}{l}\text { Question 2: Compared to the platform, what are } \\
\text { the characteristics of the platform leadership? }\end{array}$} \\
\hline $\begin{array}{l}\text { Code and } \\
\text { category }\end{array}$ & $\begin{array}{l}\text { Categorical } \\
\text { nature }\end{array}$ & $\begin{array}{l}\text { Concepts } \\
\text { contained }\end{array}$ & $\begin{array}{l}\text { Code and } \\
\text { category }\end{array}$ & $\begin{array}{l}\text { Categorical } \\
\text { nature }\end{array}$ & $\begin{array}{l}\text { Concepts } \\
\text { contained }\end{array}$ \\
\hline $\begin{array}{l}1 \text {-aa1 Multi } \\
\text { subjectivity }\end{array}$ & $\begin{array}{l}\text { Made up } \\
\text { of multiple } \\
\text { subjects }\end{array}$ & $\begin{array}{l}\text { 1-1-a1, 1-3-a2, } \\
\text { 1-5-a1, 1-9-a1, } \\
1-13-\mathrm{a} 1,1-17-\mathrm{a} 2, \\
1-19-\mathrm{a} 3,1-27-\mathrm{a} 5 \\
1-33-\mathrm{a} 1,1-39-\mathrm{a} 3 \\
1-41-\mathrm{a} 2,1-47-\mathrm{a} 3\end{array}$ & $\begin{array}{l}\text { 2-aa1 } \\
\text { General } \\
\text { properties of } \\
\text { platform }\end{array}$ & $\begin{array}{l}\text { General } \\
\text { characteristics of } \\
\text { platform }\end{array}$ & $\begin{array}{l}\text { 2-1-a1, 2-5-a1, } \\
2-7-\mathrm{a} 1,2-11-\mathrm{a} 1, \\
2-15-\mathrm{a} 1,2-19-\mathrm{a} 1, \\
2-25-\mathrm{a} 1,2-31-\mathrm{a} 1, \\
2-35-\mathrm{a} 2,2-37-\mathrm{a} 1, \\
2-43-\mathrm{a} 1,2-49-\mathrm{a} 2\end{array}$ \\
\hline $\begin{array}{l}1 \text {-aa2 } \\
\text { Trading } \\
\text { space }\end{array}$ & $\begin{array}{l}\text { Platform is } \\
\text { the space } \\
\text { of various } \\
\text { transactions }\end{array}$ & $\begin{array}{l}\text { 1-1-a3, 1-7-a1, } \\
\text { 1-9-a2, 1-11-a1, } \\
\text { 1-15-a1, 1-19-a1, } \\
\text { 1-25-a1, 1-29-a1, } \\
\text { 1-35-a2, 1-37-a3, } \\
\text { 1-43-a1, 1-49-a1 }\end{array}$ & $\begin{array}{l}\text { 2-aa2 Colla- } \\
\text { borative } \\
\text { development } \\
\text { subjects of } \\
\text { platform }\end{array}$ & $\begin{array}{l}\text { Complementary } \\
\text { product } \\
\text { developers of } \\
\text { platform }\end{array}$ & $\begin{array}{l}2-3-\mathrm{a} 2,2-9-\mathrm{a} 1, \\
2-17-\mathrm{a} 1,2-27-\mathrm{a} 1, \\
2-29-\mathrm{a} 1,2-31-\mathrm{a} 2 \\
2-39-\mathrm{a} 2,2-45-\mathrm{a} 1\end{array}$ \\
\hline $\begin{array}{l}1 \text {-aa3 } \\
\text { Information } \\
\text { exchange } \\
\text { space }\end{array}$ & $\begin{array}{l}\text { Platform is a } \\
\text { information } \\
\text { gathering } \\
\text { space }\end{array}$ & $\begin{array}{l}\text { 1-5-a3, 1-13-a3, } \\
\text { 1-15-a2, 1-23-a1, } \\
\text { 1-27-a1, 1-31-a2, } \\
\text { 1-39-a1, } \\
1-43-\mathrm{a} 1\end{array}$ & $\begin{array}{l}\text { 2-aa3 } \\
\text { Platform } \\
\text { cluster }\end{array}$ & $\begin{array}{l}\text { Multiple } \\
\text { subsidiary } \\
\text { platforms }\end{array}$ & $\begin{array}{l}\text { 2-3-a1, 2-9-a2, } \\
\text { 2-13-a1, 2-21-a1, } \\
\text { 2-25-a3, 2-33-a1, } \\
2-39-\mathrm{a} 1, \\
2-47-\mathrm{a} 1\end{array}$ \\
\hline
\end{tabular}


Continued Table 2

\begin{tabular}{|c|c|c|c|c|c|}
\hline \multicolumn{3}{|c|}{$\begin{array}{l}\text { Question 1: What are the general } \\
\text { characteristics of the platform? }\end{array}$} & \multicolumn{3}{|c|}{$\begin{array}{l}\text { Question 2: Compared to the platform, what are } \\
\text { the characteristics of the platform leadership? }\end{array}$} \\
\hline $\begin{array}{l}\text { Code and } \\
\text { category }\end{array}$ & $\begin{array}{l}\text { Categorical } \\
\text { nature }\end{array}$ & $\begin{array}{l}\text { Concepts } \\
\text { contained }\end{array}$ & $\begin{array}{l}\text { Code and } \\
\text { category }\end{array}$ & $\begin{array}{l}\text { Categorical } \\
\text { nature }\end{array}$ & $\begin{array}{l}\text { Concepts } \\
\text { contained }\end{array}$ \\
\hline $\begin{array}{l}\text { 1-aa4 Price } \\
\text { information } \\
\text { symmetry }\end{array}$ & $\begin{array}{l}\text { The } \\
\text { platform } \\
\text { price is } \\
\text { transparency } \\
\text { and easy to } \\
\text { compare }\end{array}$ & $\begin{array}{l}\text { 1-3-a1, 1-9-a3, } \\
1-13-\mathrm{a} 2,1-21-\mathrm{a} 1 \\
1-23-\mathrm{a} 2,1-31-\mathrm{a} 1 \\
1-37-\mathrm{a} 1,1-41-\mathrm{a} 1 \\
1-45-\mathrm{a} 2\end{array}$ & $\begin{array}{l}\text { 2-aa4 The } \\
\text { openness } \\
\text { of technical } \\
\text { interfaces }\end{array}$ & $\begin{array}{l}\text { Open connector } \\
\text { of outward } \\
\text { technology }\end{array}$ & $\begin{array}{l}2-1-\mathrm{a} 3,2-5-\mathrm{a} 2 \\
2-27-\mathrm{a} 3,2-31-\mathrm{a} 3 \\
2-35-\mathrm{a} 1,2-41-\mathrm{a} 1\end{array}$ \\
\hline $\begin{array}{l}\text { 1-aa5 } \\
\text { Two-sided } \\
\text { market } \\
\text { charac- } \\
\text { teristic }\end{array}$ & $\begin{array}{l}\text { Platform } \\
\text { connects } \\
\text { two-sided } \\
\text { market }\end{array}$ & $\begin{array}{l}\text { 1-1-a1, 1-7-a2, } \\
1-11-a 2,1-15-a 3 \\
1-17-a 1,1-21-a 3 \\
1-27-a 2,1-29-a 2 \\
1-47-a 1\end{array}$ & $\begin{array}{l}\text { 2-aa5 The } \\
\text { openness of } \\
\text { data }\end{array}$ & $\begin{array}{l}\text { Data calculation } \\
\text { and sharing } \\
\text { function }\end{array}$ & $\begin{array}{l}2-11-\mathrm{a} 2,2-13-\mathrm{a} 2, \\
2-19-\mathrm{a} 3,2-23-\mathrm{a} 1, \\
2-17-\mathrm{a} 1,2-29-\mathrm{a} 2, \\
2-37-\mathrm{a} 2,2-43-\mathrm{a} 3, \\
2-47-\mathrm{a} 2\end{array}$ \\
\hline $\begin{array}{l}\text { 1-aa6 User } \\
\text { scale effect }\end{array}$ & $\begin{array}{l}\text { The more } \\
\text { users, the } \\
\text { more utility }\end{array}$ & $\begin{array}{l}\text { 1-5-a2, 1-13-a4, } \\
\text { 1-21-a4, 1-27-a3, } \\
\text { 1-31-a3, 1-33-a2, } \\
1-43-\mathrm{a} 2 \\
1-49-\mathrm{a} 2\end{array}$ & $\begin{array}{l}2 \text {-aa6 } \\
\text { Platform } \\
\text { rule design }\end{array}$ & $\begin{array}{l}\text { The power and } \\
\text { ability of rule } \\
\text { design and } \\
\text { allocation of } \\
\text { resources }\end{array}$ & $\begin{array}{l}2-1-\mathrm{a} 2,2-3-\mathrm{a} 3, \\
2-11-\mathrm{a} 3,2-17-\mathrm{a} 2, \\
2-21-\mathrm{a} 2,2-33-\mathrm{a} 2 \\
2-49-\mathrm{a} 1\end{array}$ \\
\hline $\begin{array}{l}\text { 1-aa7 Scale } \\
\text { effects of } \\
\text { product or } \\
\text { service }\end{array}$ & $\begin{array}{l}\text { The greater } \\
\text { the product } \\
\text { or service } \\
\text { of platform, } \\
\text { the more } \\
\text { utility }\end{array}$ & $\begin{array}{l}1-11-a 3,1-15-a 4 \\
1-19-a 2,1-21-a 2 \\
1-37-a 2,1-39-a 4 \\
1-47-a 1\end{array}$ & $\begin{array}{l}2 \text {-aa7 } \\
\text { Platform } \\
\text { supervision }\end{array}$ & $\begin{array}{l}\text { The power } \\
\text { of platform } \\
\text { operation } \\
\text { supervision }\end{array}$ & $\begin{array}{l}2-3-\mathrm{a} 4,2-7-\mathrm{a} 2, \\
2-9-\mathrm{a} 3,2-15-\mathrm{a} 2, \\
2-23-\mathrm{a} 2,2-37-\mathrm{a} 4, \\
2-41-\mathrm{a} 2,2-43-\mathrm{a} 2, \\
2-47-\mathrm{a} 3\end{array}$ \\
\hline $\begin{array}{l}\text { 1-aa8 Low } \\
\text { marginal } \\
\text { cost }\end{array}$ & $\begin{array}{l}\text { The cost } \\
\text { of product } \\
\text { search } \\
\text { and the } \\
\text { transaction } \\
\text { marginal } \\
\text { cost are low }\end{array}$ & $\begin{array}{l}\text { 1-3-a3, 1-25-a2, } \\
\text { 1-29-a3, 1-35-a1, } \\
1-37-a 4,1-45-a 1 \\
1-49-a 4\end{array}$ & $\begin{array}{l}\text { 2-aa8 } \\
\text { Dynamic } \\
\text { innovation } \\
\text { drive }\end{array}$ & $\begin{array}{l}\text { Dynamic } \\
\text { innovation } \\
\text { mechanism and } \\
\text { capability of } \\
\text { driving platform }\end{array}$ & $\begin{array}{l}2-5-a 3,2-13-a 3, \\
2-19-a 2,2-21-a 3, \\
2-25-a 2,2-27-a 2, \\
2-37-a 3,2-45-a 2\end{array}$ \\
\hline \multirow{2}{*}{$\begin{array}{l}\text { 1-aa9 } \\
\text { Multiplicity } \\
\text { of user } \\
\text { identity }\end{array}$} & \multirow{2}{*}{$\begin{array}{l}\text { Platform } \\
\text { users have } \\
\text { multiple } \\
\text { identities }\end{array}$} & \multirow{2}{*}{$\begin{array}{l}1-7-a 3,1-17-a 3, \\
1-23-a 3,1-27-a 4, \\
1-33-a 3,1-39-a 2, \\
1-47-a 2 \\
1-49-a 3\end{array}$} & \multicolumn{3}{|c|}{$\begin{array}{l}\text { Question 4: what are the characteristics of the } \\
\text { recommended network entrepreneurial platform } \\
\text { leadership? }\end{array}$} \\
\hline & & & $\begin{array}{l}\text { Code and } \\
\text { category }\end{array}$ & $\begin{array}{l}\text { Categorical } \\
\text { nature }\end{array}$ & $\begin{array}{l}\text { Concepts } \\
\text { contained }\end{array}$ \\
\hline \multicolumn{3}{|c|}{$\begin{array}{l}\text { Question 3: what are the characteristics of the } \\
\text { network entrepreneurial platform leadership? }\end{array}$} & \multirow{2}{*}{$\begin{array}{l}\text { 4-aal } \\
\text { Huge user } \\
\text { resources }\end{array}$} & \multirow[t]{2}{*}{$\begin{array}{l}\text { There are huge } \\
\text { user resources }\end{array}$} & \multirow{2}{*}{$\begin{array}{l}\text { 4-7-a1, 4-11-a1, } \\
\text { 4-13-a1, 4-25-a1, } \\
\text { 4-29-a1, 4-35-a1, } \\
\text { 4-41-a1, } \\
\text { 4-47-a2 }\end{array}$} \\
\hline $\begin{array}{l}\text { Code and } \\
\text { category }\end{array}$ & $\begin{array}{l}\text { Categorical } \\
\text { nature }\end{array}$ & $\begin{array}{l}\text { Concepts } \\
\text { contained }\end{array}$ & & & \\
\hline $\begin{array}{l}\text { 3-aal } \\
\text { General } \\
\text { charac- } \\
\text { teristics of } \\
\text { platform } \\
\text { leadership }\end{array}$ & $\begin{array}{l}\text { General } \\
\text { features of } \\
\text { platform } \\
\text { leadership }\end{array}$ & $\begin{array}{l}\text { 3-5-a1, 3-7-a1, } \\
\text { 3-11-a1, 3-19-a1, } \\
\text { 3-25-a1, 3-29-a1, } \\
\text { 3-31-a2, } \\
\text { 3-35-a1, 3-45-a1 }\end{array}$ & $\begin{array}{l}\text { 4-aa2 Rich } \\
\text { technical } \\
\text { resources }\end{array}$ & $\begin{array}{l}\text { With strong } \\
\text { technology and } \\
\text { data support } \\
\text { services }\end{array}$ & $\begin{array}{l}\text { 4-1-a1, 4-13-a2, } \\
\text { 4-7-a2, 4-21-a1, } \\
\text { 4-31-a1, 4-33-a1, } \\
\text { 4-39-a2 }\end{array}$ \\
\hline
\end{tabular}


End of Table 2

\begin{tabular}{|c|c|c|c|c|c|}
\hline \multicolumn{3}{|c|}{$\begin{array}{l}\text { Question 1: What are the general } \\
\text { characteristics of the platform? }\end{array}$} & \multicolumn{3}{|c|}{$\begin{array}{l}\text { Question 2: Compared to the platform, what are } \\
\text { the characteristics of the platform leadership? }\end{array}$} \\
\hline $\begin{array}{l}\text { Code and } \\
\text { category }\end{array}$ & $\begin{array}{l}\text { Categorical } \\
\text { nature }\end{array}$ & $\begin{array}{l}\text { Concepts } \\
\text { contained }\end{array}$ & $\begin{array}{l}\text { Code and } \\
\text { category }\end{array}$ & $\begin{array}{l}\text { Categorical } \\
\text { nature }\end{array}$ & $\begin{array}{l}\text { Concepts } \\
\text { contained }\end{array}$ \\
\hline $\begin{array}{l}\text { 3-aa2 Inter- } \\
\text { net appli- } \\
\text { cation }\end{array}$ & $\begin{array}{l}\text { Wide appli- } \\
\text { cation of the } \\
\text { Internet }\end{array}$ & $\begin{array}{l}\text { 3-1-a1, 3-2-a2, } \\
3-9-\mathrm{a} 1,3-13-\mathrm{a} 1, \\
3-17-\mathrm{a} 1,3-25-\mathrm{a} 2 \\
3-27-\mathrm{a} 1,3-43-\mathrm{a} 1 \\
3-49-\mathrm{a} 1\end{array}$ & $\begin{array}{l}\text { 4-aa3 Brand } \\
\text { effect }\end{array}$ & $\begin{array}{l}\text { With good } \\
\text { brand image }\end{array}$ & $\begin{array}{l}\text { 4-11-a2, 4-9-a1, } \\
\text { 4-13-a3, 4-15-a1, } \\
\text { 4-23-a2, 4-27-a1 }\end{array}$ \\
\hline $\begin{array}{l}\text {-aa3 } \\
\text { Virtual } \\
\text { nature }\end{array}$ & $\begin{array}{l}\text { Online } \\
\text { trading and } \\
\text { obvious } \\
\text { interaction }\end{array}$ & $\begin{array}{l}\text { 3-3-a2, 3-9-a2, } \\
3-15-\mathrm{a} 3,3-19-\mathrm{a} 2 \\
3-23-\mathrm{a} 1,3-27-\mathrm{a} 2 \\
3-33-\mathrm{a} 1 \\
3-37-\mathrm{a} 1\end{array}$ & $\begin{array}{l}4 \text {-aa4 } \\
\text { Industry } \\
\text { status }\end{array}$ & $\begin{array}{l}\text { Leading } \\
\text { position in the } \\
\text { industry }\end{array}$ & $\begin{array}{l}\text { 4-5-a1, 4-13-a4, } \\
\text { 4-11-a2, 4-17-a1, } \\
\text { 4-25-a2, 4-45-a1 }\end{array}$ \\
\hline $\begin{array}{l}\text { 3-aa4 } \\
\text { Entrepre- } \\
\text { neurial } \\
\text { motivation }\end{array}$ & $\begin{array}{l}\text { Significant } \\
\text { entrepre- } \\
\text { neurial } \\
\text { motivation }\end{array}$ & $\begin{array}{l}3-1-\mathrm{a} 3,3-11-\mathrm{a} 2 \\
3-15-\mathrm{a} 2,3-21-\mathrm{a} 2 \\
3-33-\mathrm{a} 2,3-41-\mathrm{a} 1 \\
3-45-\mathrm{a} 2\end{array}$ & $\begin{array}{l}\text { 4-aa5 Open } \\
\text { innovation }\end{array}$ & $\begin{array}{l}\text { Openness, } \\
\text { compatibility } \\
\text { and innovation }\end{array}$ & $\begin{array}{l}\text { 4-12-a2, 4-31-a2, } \\
\text { 4-41-a2, 4-47-a1, } \\
\text { 4-49-a2 }\end{array}$ \\
\hline \multirow[t]{2}{*}{$\begin{array}{l}\text { 3-aa5 Open } \\
\text { innovation }\end{array}$} & \multirow{2}{*}{$\begin{array}{l}\text { Open } \\
\text { innovation } \\
\text { mechanism }\end{array}$} & \multirow{2}{*}{$\begin{array}{l}\text { 3-1-a2, 3-17-a2, } \\
\text { 3-27-a3, 3-35-a2, } \\
3-37-a 2\end{array}$} & \multicolumn{3}{|c|}{$\begin{array}{l}\text { Question 5: what are the core characteristics of the } \\
\text { network entrepreneurial platform leadership? }\end{array}$} \\
\hline & & & $\begin{array}{l}\text { Code and } \\
\text { category }\end{array}$ & $\begin{array}{l}\text { Categorical } \\
\text { nature }\end{array}$ & Concepts contained \\
\hline $\begin{array}{l}\text { 3-aa6 } \\
\text { Multi node } \\
\text { interaction }\end{array}$ & $\begin{array}{l}\text { Many } \\
\text { stakeholders, } \\
\text { and active } \\
\text { interaction }\end{array}$ & $\begin{array}{l}3-5-a 3,3-29-a 2 \\
3-35-a 1,3-39-a 2, \\
3-43-a 2,3-47-a 2 \\
3-49-a 3\end{array}$ & $\begin{array}{l}\text { 5-aal } \\
\text { Competitive } \\
\text { resources }\end{array}$ & $\begin{array}{l}\text { Platform } \\
\text { resources with } \\
\text { competitive } \\
\text { advantage }\end{array}$ & $\begin{array}{l}\text { 5-3-a1, 5-9-a1, } \\
\text { 5-13-a1, 5-23-a1, } \\
\text { 5-27-a1, 5-31-a1, } \\
\text { 5-37-a1, 5-41-a1 }\end{array}$ \\
\hline $\begin{array}{l}3 \text {-aa7 Cross } \\
\text { level and } \\
\text { organi- } \\
\text { zational } \\
\text { connection }\end{array}$ & $\begin{array}{l}\text { The complex } \\
\text { relationship } \\
\text { between } \\
\text { various } \\
\text { subjects } \\
\text { and the } \\
\text { nonlinear } \\
\text { relationship }\end{array}$ & $\begin{array}{l}\text { 3-7-a2, 3-23-a2, } \\
\text { 3-31-a3, 3-39-a3, } \\
\text { 3-39-a1, 3-45-a2 }\end{array}$ & $\begin{array}{l}\text { 5-aa2 } \\
\text { Business } \\
\text { rules and } \\
\text { patterns with } \\
\text { continuous } \\
\text { innovation }\end{array}$ & $\begin{array}{l}\text { Constant } \\
\text { innovation of } \\
\text { entrepreneurial } \\
\text { model and } \\
\text { business rules }\end{array}$ & $\begin{array}{l}\text { 5-5-a1, 5-11-a1, } \\
\text { 5-23-a2, 5-27-a2, } \\
\text { 5-29-a1, 5-39-a1 }\end{array}$ \\
\hline $\begin{array}{l}\text { 3-aa8 } \\
\text { Network } \\
\text { externality }\end{array}$ & $\begin{array}{l}\text { Network } \\
\text { externality } \\
\text { is extremely } \\
\text { significant }\end{array}$ & $\begin{array}{l}\text { 3-33-a3, 3-41-a2, } \\
\text { 3-45-a3, 3-47-a1, } \\
\text { 3-49-a2 }\end{array}$ & $\begin{array}{l}\text { 5-aa3 Open } \\
\text { system of } \\
\text { platform }\end{array}$ & $\begin{array}{l}\text { An open } \\
\text { system with } \\
\text { large and rich } \\
\text { ecology }\end{array}$ & $\begin{array}{l}\text { 5-9-a2, 5-29-a2, } \\
\text { 5-37-a2, 5-47-a1, } \\
\text { 5-49-a1 }\end{array}$ \\
\hline $\begin{array}{l}\text { 3-aa9 } \\
\text { Entrepre- } \\
\text { neurial } \\
\text { behavior }\end{array}$ & $\begin{array}{l}\text { Frequent } \\
\text { entrepre- } \\
\text { neurial } \\
\text { behavior }\end{array}$ & $\begin{array}{l}\text { 3-3-a1, 3-5-a2, } \\
\text { 3-15-a1, 3-21-a1, } \\
\text { 3-25-a3, 3-33-a4, } \\
3-45-\mathrm{a} 4\end{array}$ & $\begin{array}{l}\text { 5-aa4 } \\
\text { Platform } \\
\text { strategy } \\
\text { decision }\end{array}$ & $\begin{array}{l}\text { Forward-looking } \\
\text { strategic } \\
\text { decision }\end{array}$ & $\begin{array}{l}\text { 5-9-a3, 5-19-a1, } \\
\text { 5-23-a3, 5-33-a1, } \\
\text { 5-41-a2, 5-47-a2 }\end{array}$ \\
\hline
\end{tabular}

\subsection{Axial coding}

Axial coding mainly is the link between finding and building categories, and through the relations between cause and result, contexts and structures to subdivide the topic word group to refine the first words, doing a further research on each of them, i.e. the main category. 
Since this research primarily puts its focus on analyzing characteristic structure model, the research will do the axial coding from the structural relationship between the original categories.

Though the categories labeled by " 2 -aal" and " 3 -aal" have no essential connotation, they illustrate the progressive relationship between them. That is, the leadership platform contains the common characteristic of platforms, while the network entrepreneurial leadership platform also includes the relevant characteristics of the leadership platform. Apart from this, paralleling or structural inclusion relations also exist in the categories under each question. Based on the horizontal and vertical relational network among categories, combining the categorical features in Table 2 and through the collection analysis; further, the researchers sum up the 32 categories which have deleted "2-aal" and " 3 -aa1" without essential connotation into 11 main categories. In order to increase the efficiency and credibility of the research, the researchers have invited another researcher to respectively inspect the subordination of these 32 categories, and the degree of unity by counting the Cohen's Kappa index. Therefore, if the $\mathrm{K}$ value of the symmetrical price information category is below 0.4 , then it should be deleted. While the $\mathrm{K}$ value of the remaining 31 categories all is above 0.75 , then they should be kept. After the analysis above, the research finally forms 11 main categories and 31 according original categories (two of them are the same), whose codes are transformed with "A + serial number". The details are shown in Table 3:

Table 3. Main categories and corresponding categories which are formed by axial coding

\begin{tabular}{|l|l|l|}
\hline \multicolumn{1}{|c|}{ Main category } & \multicolumn{1}{|c|}{ Explanation } & \multicolumn{1}{c|}{ Corresponding category } \\
\hline $\begin{array}{l}\text { A1 Multi-homing } \\
\text { of user }\end{array}$ & $\begin{array}{l}\text { It consists of a number of main } \\
\text { components. The user can participate } \\
\text { in platform interaction and transaction } \\
\text { based on multiple identities. }\end{array}$ & $\begin{array}{l}\text { 1-aa1 Multi subjectivity } \\
\text { 1-aa9 Multiplicity of user identity }\end{array}$ \\
\hline $\begin{array}{l}\text { A2 Spatial } \\
\text { clustering }\end{array}$ & $\begin{array}{l}\text { It is a kind of market and specific } \\
\text { space of transaction and information } \\
\text { interaction. }\end{array}$ & $\begin{array}{l}\text { 1-aa2 Trading space } \\
\text { 1-aa3 Information exchange space }\end{array}$ \\
\hline $\begin{array}{l}\text { A3 Multi-platform } \\
\text { symbiosis of } \\
\text { ecological } \\
\text { community }\end{array}$ & $\begin{array}{l}\text { It is associated with the two-saided } \\
\text { market platform, development platform, } \\
\text { and builds ecological community of } \\
\text { platform with cooperative development. }\end{array}$ & $\begin{array}{l}\text { 1-aa5 Two-sided market } \\
\text { characteristic } \\
\text { 2-aa2 Collaborative development } \\
\text { subjects of platform } \\
\text { 2-aa3 Platform cluster }\end{array}$ \\
\hline $\begin{array}{l}\text { A4 Network } \\
\text { externality }\end{array}$ & $\begin{array}{l}\text { User scale effect brings network } \\
\text { externality of platform members, } \\
\text { product and service scale effects bring } \\
\text { the network externality of the platform } \\
\text { application, so as to reduce the marginal } \\
\text { costs of subject transaction and } \\
\text { interaction. }\end{array}$ & $\begin{array}{l}\text { 1-aa6 User scale effect } \\
\text { 1-aa7 Scale effects of product or } \\
\text { service } \\
\text { 1-aa8 Low marginal cost } \\
\text { 3-aa8 Significant network externality }\end{array}$ \\
\hline A5 Internet effect & $\begin{array}{l}\text { The embedding of the internet } \\
\text { technology brings the platform } \\
\text { virtualization. }\end{array}$ & $\begin{array}{l}\text { 3-aa2 Internet application } \\
\text { 3-aa3 Virtual nature }\end{array}$ \\
\hline
\end{tabular}


End of Table 3

\begin{tabular}{|l|l|l|}
\hline \multicolumn{1}{|c|}{ Main category } & \multicolumn{1}{|c|}{ Explanation } & \multicolumn{1}{c|}{ Corresponding category } \\
\hline $\begin{array}{l}\text { A6 } \\
\text { Entrepreneurial } \\
\text { orientation }\end{array}$ & $\begin{array}{l}\text { The strong entrepreneurial motivation of } \\
\text { Platform leadership and users can drive } \\
\text { the multi linear entrepreneurial behavior. }\end{array}$ & $\begin{array}{l}\text { 3-aa4 Entrepreneurial motivation } \\
\text { 3-aa9 Entrepreneurial behavior }\end{array}$ \\
\hline $\begin{array}{l}\text { A7 Embedded } \\
\text { collaborative open } \\
\text { innovation }\end{array}$ & $\begin{array}{l}\text { Through the opening of the platform } \\
\text { technological connector, data opening } \\
\text { and sharing, it can realize the external } \\
\text { embedding, so as to drive the } \\
\text { collaborative open innovation of internal } \\
\text { and external subject of the platform. }\end{array}$ & $\begin{array}{l}\text { 2-aa4 The openness of technical } \\
\text { interfaces } \\
\text { 2-aa5 The openness of data } \\
\text { 2-aa8 Dynamic innovation drive } \\
\text { 3-aa5, 4-aa5 Open innovation } \\
\text { 5-aa3 Open system of platform }\end{array}$ \\
\hline $\begin{array}{l}\text { A8 } \\
\text { Entrepreneurial } \\
\text { model of network } \\
\text { systematism }\end{array}$ & $\begin{array}{l}\text { Multi linear entrepreneurial model } \\
\text { of platform entrepreneurial subjects, } \\
\text { which characterized as multi node, } \\
\text { cross level, cross organizational, } \\
\text { promotes the continuous innovation and } \\
\text { transformation of the platform business } \\
\text { model, and obtains new competitive } \\
\text { advantage. }\end{array}$ & $\begin{array}{l}\text { 3-aa6 Multi node interaction } \\
\text { 3-aa7 Cross level and organizational } \\
\text { connection } \\
\text { 5-aa2 Business rules and patterns } \\
\text { with continuous innovation }\end{array}$ \\
\hline $\begin{array}{l}\text { A9 Platform } \\
\text { leadership power }\end{array}$ & $\begin{array}{l}\text { Platform power such as platform rule } \\
\text { definition, supervision, strategic decision } \\
\text { and so on. }\end{array}$ & $\begin{array}{l}\text { 2-aa6 Platform rule design } \\
\text { 2-aa7 Platform supervision } \\
\text { 5-aa4 Platform strategic decision }\end{array}$ \\
\hline $\begin{array}{l}\text { A10 Platform } \\
\text { resources }\end{array}$ & User resources, technical resources. & $\begin{array}{l}\text { 4-aa1 Huge user resources } \\
\text { 4-aa2 Rich technical resources }\end{array}$ \\
\hline $\begin{array}{l}\text { A11 Platform } \\
\text { brand assets }\end{array}$ & $\begin{array}{l}\text { Brand assets such as good brand image, } \\
\text { market position and so on. }\end{array}$ & $\begin{array}{l}\text { 4-aa3 Brand effect } \\
\text { 4-aa4 Industry status }\end{array}$ \\
\hline
\end{tabular}

\subsection{Selective coding}

Selective coding is the process during which centered on the core categories and systematically connected with other categories, inspects the relationship between them and replenishes the categories whose conception hasn't developed fully. The core categories of the research are the network entrepreneurial leadership platform characteristics, which are also through the whole research. During the course of preparing for the interviewing outline, the researchers extend from the platform characteristics to the core ones of the network entrepreneurial leadership platform step by step. When refining the original and main categories, the categories "2-aa1" and "3-3aa1" manifests that there exists a logically structural relationship among platforms, leadership platforms and network entrepreneurial leadership platforms. It is based on the method of above research that the research, centered on the core categories and following the logically structural relationship, sets up the network entrepreneurial leadership platform's model of double stories, three types and multidimensional structure. The details are shown in Figure 2. 


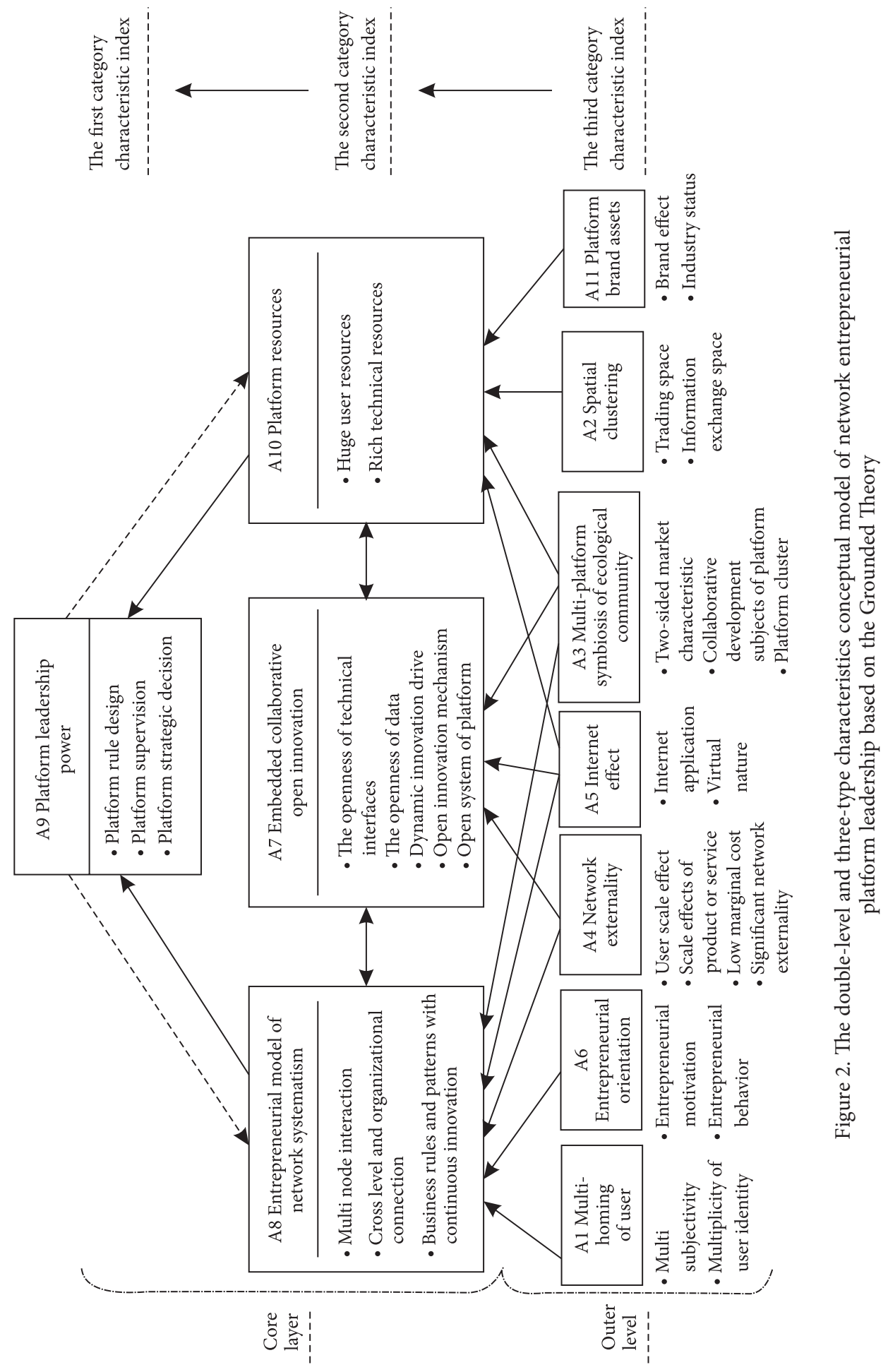




\subsection{Testing the saturability, credibility and efficiency of theory}

In the qualitative research, the test of theoretical saturability is regarded as the standards of judging whether collecting samples should be prohibited or not, that is, after collecting new data and stopping generating new concepts and categories the research achieves the theoretical saturability. During the course of designing methods and theoretical sampling, the source of data that tests the theoretical saturability is from 24 samples. According to the procedural flow of Grounded Theory, the researchers operate open coding, axial coding and selective coding on these 24 samples, refining 235 concepts, 32 original categories and 9 main categories. There generates no new concepts, categories and relations, in which the researchers put the following 5 original analytic units and concepts as cases to proof:

Case 1: The platform is an exchanging space (1-4-a2) where many subjects take part in (14-a1). The concept and initialized category embodied by the original analytic unit "1-4-a2" are "multiple subjects" and the main category is "users' multiple attributes". While what the analytic unit "1-4-a2" represents are respectively "exchanging space" and "space clustering".

Case 2: The platform leadership should possess the ability to control all members (2-32a4). The concept of this analytic unit after refinement is the ability of supervising the platform, the initialized category is platform supervision and the main category is the power of platform leadership.

Case 3: The primary character of the network entrepreneurial platform to confirm is the application of the Internet (3-20-a1). The concept and initialized category of this analytic unit after refinement are the "application of the Internet", while the main categories embodied is the effect of the Internet.

Case 4: In my point of view, as an excellent leader of the network entrepreneurial platform, the most outstanding feature is the existence of a large number of users (4-46-a2). The concept and initialized category of this analytic unit are a large number of users, while the main categories embodied is the platform resource.

Besides the test of theoretical saturability, it is also vital to test the efficiency and credibility of the qualitative research. In order to raise the efficiency of the research, when designing the interviewing outlines, the experts probe into the presupposed questions through brainstorm and generate the formal interviewing outline. The samples are composed of 4 different individuals of various statuses who participate in the interview according to the principle of typicality, while the number of samples is based on the experimental principle of 20-30 people in qualitative research. The data collection should follow the triangle rule (Patton, 2002) of evidence as well as possible, from different information sources like the on-spot interviewing transcript and taping and second-hand information of cases. In addition, during the model construction the researchers select the analytic units partly by using the software - NVIVO8.0. However, when testing the theoretical saturability the researchers don't apply the above software and get another result so that they can compare their differences. In order to increase the credibility of research, the researchers invite another one to independently test the code's subordination and analyze the uniformity by applying the software. After the theoretical construction, the researchers use the new samples to test the theoretical saturability and have another brief interview when the first interview has finished for 2 months for decreasing random errors as far as possible. 


\section{Findings}

\subsection{Interaction relation of multidimensional structure}

Figure 2 shows the network entrepreneurial platform leadership possesses the logical structure relation of double layers and triple categories. It also includes 11 concepts and 30 threelevel indexes. Model can be divided into two levels of core level and external level. Core level is the key character of network entrepreneurial platform leadership, including platform leadership power, embedded collaborative open innovation, platform resource and entrepreneurial model of network systematism; external level is the general character of network entrepreneurial platform leadership, including 7 characters, such as multi-homing of user and entrepreneurial oriented character.

In addition, based on the logical structure relation of four characters of core level, researchers further divide it into first character index and second character index and thus form the multi-dimensional structure of the third category. Among them, the first character is platform leadership power, the second character is embedded collaborative open innovation, platform resource and entrepreneurial model of network systematism. And the third character index is peripheral character. Apart from possessing structural relation, these three character indexes also have logical interactive relation: platform leadership power is the key of the whole character model. For one thing, the formation of its power comes from the mechanism settlement of embedded collaborative open innovation, platform resource guarantee and the operation of entrepreneurial model of network systematism. For another, the occurrence of platform leadership power further strengthens the operation of collaborative open innovation, platform resource expansion and the operation of entrepreneurial model of network systematism. As for the three character indexes in the external level respectively support three second character indexes: multi subjectivity and homing of users give rise to the joint character of platform leadership network organization. The ecological community character of network externality and multi-platform co-existence realizes the multi-line connecting relation of multi-level and organization. And entrepreneurial motivation and behavior, and network effect drives the platform leadership network entrepreneurial orientation; internet effect provides condition for platform skill, data opening and sharing. The ecological community character of network externality and multi-platform co-existence promotes the platform multi-subjectivity embedding and collaborative open innovation; internet effect also provides opportunity for the occurrence of user and skill resource. The space collectiveness and multi-platform of ecological community character further broaden the resource scale effect and resource fission. The platform brand asset improves the platform resource quality.

Generally speaking, network entrepreneurial platform leadership is the pattern that based on network platform resource, cooperative opening innovation mechanism and network organization. In the network system of multi-platform co-existence, it possesses the core platform of leadership powers, such as regulation definition, supervising management and strategical decision. It conducts the entrepreneurial behavior by driving the network platform subjectivity for the purpose of gaining entrepreneurial rent. It possesses character of distinct entrepreneurial orientation. 


\subsection{The first category characteristic index: personality leadership power of platform leadership}

Just as enterprise is the personality installment of entrepreneur, the organization with nonpersonality subjectivity also possesses the personality character which is similar with individual personality and can be perceived by the outside, that is, Organization Personality. Among them, a super important organization personality dimension is power. This kind of organization personality power exhibits itself by the forms of organizational regulations, institutions and organizational culture. As an organization, the reason that network entrepreneurial platform leadership differences from general platform is mainly for its personality leadership power in the platform community: firstly, by setting some regulations, such as the platform business boundary, the skill standard and opening level, competitive mechanism with competitive relator, rent allocation and resource configuration, gaining the personality leadership power status; secondly, based on the leadership status, the platform leadership conduct supervision and management on the sub-platform and subjectivity, showing the personality leadership power; thirdly, as the platform leadership of overall network ecological system key, it takes the responsibility of leadership the platform development and developing platform strategies. During this process, the personality leadership power effect of network entrepreneurial platform leadership is similar with Trickle-down, which is the interaction of multi-level subjectivities. The effect possesses multi-level and embedded characters. It is exactly the interaction effect between the power status and effect of personality leader that enables network entrepreneurial platform leadership to sit in the core position in the overall network organization.

\subsection{The second category characteristic index 1: Embedded collaborative open innovation}

The true vitality of platform leadership not lies in the individual development, but lies in the cooperative development of the whole platform network under the personality leadership power. In order to realize this platform development prospect, platform leadership needs to possess two conditions: firstly, as network organizing form, network entrepreneurial platform leadership cannot build organizing double channel updating system until changing from closed transformation to opening innovation. In this way, it can provide condition for multi-platform participation, and the integration and value of external and internal resource of platform. It can also realize the transformation from single platform to multi-platform network system. Secondly, the platform leadership is same as other organizations, which deeply influenced by the relation and structure of internal and external network. Only if multisubjectivity embed can it gives rise to knowledge and innovation effect, builds the interaction channel between platform leadership and multi-subjectivity, and realizes the circulation of information flow, physical distribution, technology flow and capital flow. During the practical process, only if it possesses two conditions can it builds the network entrepreneurial platform leadership. Therefore, from the perspective of the occurrence and evolution of platform leadership, embedded open innovation is exactly its internal driving force. 


\subsection{The second category characteristic index 2: platform double-resources that based on interactive resource}

Resource scarcity and importance determine organization's dependence degree on environment and thus enable power to become obvious phenomenon. Dependence is the opposite side of power. However, not all of the resources can give rise to dependent power, because the dependence degree that created by resource is limited by the influence of resource importance, the degree of gaining or determining resource usage and substitute resource. The reason that network entrepreneurial platform leadership can gain leadership power is mainly because that it possesses the user resource and technical resource that other subjectivities are lacking of. Among them, the brand effect and business status of platform leadership are the important factors of improving platform resource scarcity, importance and irreplaceability.

Meanwhile, as soon as external subjectivity embeds in network entrepreneurial platform leadership, they will give rise to adhesiveness when gaining resources and using them. The power status of platform leadership will be strengthened. However, the resource independence relation between platform leadership and external subjectivity isn't unilateral and static. Instead, it can conduct interaction through competitive independence or co-existence independence. The reason that network entrepreneurial platform leadership needs to open connector and resource is that it does not possesses all sustainable resources. It possesses similar resource independence for external subjectivity. This interaction character shows stronger under the influence of internet effect, space agglomeration and co-existence character. The interactive action that created by resource interaction becomes more frequent. This is exactly the internal recessive motivation that hides in the complex network platform entrepreneurial behavior.

\subsection{The second category characteristic index 3: new Entrepreneurial model of network systematism based on network platform}

The essence of career-creating is the re-combination of innovation and resource, which is the productive management of new productive operation and new maintaining way. Entrepreneurial pattern is the operational pattern that has been gradually forming and perfecting during the process of career-creating. It is a special commercial pattern. Among them, the network that embedded by career creator is the important resource of starting the career. It became the main channel for enterprising organization by lower cost. As the network entrepreneurial platform leadership that based on internet effect, the multi-subjectivity, multiproperty and externality pushed the network structure of platform to show the character of massive scale, strong relation strength and multi-relations. This kind of networking character with multi-node and multi-line drives the occurrence of every sub-platform on the platform leadership, such as double market platform entrepreneurship and platform develops sub-platform to create career and so on. They cooperatively built the network relation with multi-subjectivity, and the network organizing entrepreneurial pattern with cross-level and organization. This new entrepreneurial pattern is different from traditional establishment of new enterprise. It is not the same with traditional enterprise but is the new entrepreneurial pattern that based on network platform. 


\section{Conclusions}

This research comprehensively adopts the explosive research methods of classical Grounded Theory, Programming Grounded Theory and Structure Grounded Theory. Based on the leadership research of overseas platform leadership and the real background of domestic platform entrepreneurial economy, it put forward the research topic of network entrepreneurial platform leadership. In addition, it also built the double-level three characters concept model of network entrepreneurial platform leadership by the standard research process of open coding, principal coding and choosing coding. This research possesses the innovation character in the aspect of using research methods, objectives and contents. It also provided theoretical reference for network entrepreneurial platform leadership to some extent. However, as a qualitative research, it is inevitably lack of the scientific and prudent characters that needed for qualitative research. Therefore, this research still suffered from the difficulty of Grounded Theory, that is "High attention and objective emphasis but still be influenced by subjectivity". Based on the shortcoming of the research, researchers can conduct indexation on this research concept model, form the practical quantitative index system, combine quantitative research method to conduct variable checking and thus certificate or revise the theoretical concept model of this research. Meanwhile, the complex interaction relation among every main category that put forward by this research still has not been analyzed deeply and needs to research in the future. Apart from this, under the background of platform entrepreneurial economy, power competition between platform leadership and members, the factor and process of network organizing entrepreneurial pattern, the user coordinating entrepreneurship that based on Embedded collaborative open innovation and the building of network entrepreneurial platform community and ecological system are all worthy to be further researched.

\section{Acknowledgments}

The relevant researches done in this paper are supported by Zhejiang Soft Science Research Project, China (2019C35050); Humanity and Social Science Youth foundation of Ministry of Education of China (17YJA630052); Zhejiang Philosophy and Social Science Planning Project, China (16NDJC308YBM); Zhejiang Natural Science foundation, China (ly14g020002).

\section{Reference}

Adner, R., \& Kapoor, R. (2010). Value creation in innovation ecosystems: how the structure of technological interdependence affects firm performance in new technology generations. Strategic Management Journal, 31(3), 306-333. https://doi.org/10.2139/ssrn.1353582

Akbar, Y. H., \& Tracogna, A. (2018). The sharing economy and the future of the hotel industry: Transaction cost theory and platform economics. International Journal of Hospitality Management, 71, 91-101. https://doi.org/10.1016/j.ijhm.2017.12.004

Aldiabat, K. M., \& Navenec, L. (2018). Data saturation: the mysterious step in grounded theory method. The Qualitative Report, 23(1), 245-261. 
Bartunek, J. M., Rynes, S. L., \& Ireland, R. D. (2006). What makes management research interesting and why does it matter? Academy of Management Journal, 49(1), 9-15. https://doi.org/10.5465/amj.2006.20785494

Cusumano, M. A. (2011). Platform wars come to social media. Communications of the ACM, 54(4), 31-33._https://doi.org/10.1145/1924421.1924433

Dougherty, D., \& Dunne, D. (2011). Organizing ecologies of complex innovation. Organization Science, 22(5), 1214-1223. https://doi.org/10.1287/orsc.1100.0605

Fang, Y. H., \& Tan, Q. M. (2017). Research on leadership strategy of new industry innovation platform based on evolutionary game. Science and Technology Management Research, 12, 159-166.

Fassinger, R. E. (2005). Paradigms, praxis, problems, and promise: Grounded theory in counseling psychology Research. Journal of Counseling Psychology, 52(2), 156-166. https://doi.org/10.1037/0022-0167.52.2.156

Gawer, A. (2014). Bridging differing perspectives on technological platforms: Toward an integrative framework. Research Policy, 43(7), 1239-1249. https://doi.org/10.5465/ambpp.2014.278

Gawer, A., \& Cusumano, M. A. (2007). Platform leadership: How Intel, Microsoft and Cisco drive industry innovation. Guangdong: Guangdong Economic Press.

Gawer, A., \& Henderson, R. (2007). Platform owner entry and innovation in complementary markets: Evidence from Intel. Journal of Economics and Management Strategy, 16(1), 1-34. https://doi.org/10.1111/j.1530-9134.2007.00130.x

Glaer, B. G., Strauss, A. L., \& Strutzel, E. (1968). The discovery of grounded theory: strategies for qualitative research. Nursing Research, 17(4), 377-380. https://doi.org/10.1097/00006199-196807000-00014

Iansiti, M., \& Levien, R. (2004). The keystone advantage: what the new dynamics of business ecosystems mean for strategy, innovation, and sustainability. Harvard Business School Press.

Jia, X. D., \& Tan, X. H. (2010). The actual value of the classical grounded theory and its spirit to China management Research. Chinese Journal of Management, 7(5), 656-665.

Langley, P., \& Leyshon, A. (2017). Platform capitalism: the intermediation and capitalization of digital economic circulation. Finance and Society, 3(1), 11-31. https://doi.org/10.2218/finsoc.v3i1.1936

Lee, S. M., Kim, T., Noh, Y., \& Lee, B. (2010). Success factors of platform leadership in web 2.0 service business. Service Business, 4(2), 89-103. https://doi.org/10.1007/s11628-010-0093-3

Luo, M., \& Du, H. Y. (2018). Real options in platform leadership. China Industrial Economics, 2, 82-99.

McIntyre, D. P., \& Srinivasan, A. (2017). Networks, platforms, and strategy: Emerging views and next steps. Strategic Management Journal, 38(1), 141-160. https://doi.org/10.1002/smj.2596

Nambisan, S., \& Sawhney, M. (2011). Orchestration processes in network-centric innovation: evidence from the field. Academy of Management Perspectives, 25(3), 40-57. https://doi.org/10.5465/AMP.2011.63886529

Nambisan, S., Siegel, D., \& Kenney, M. (2018). On open innovation, platforms, and entrepreneurship. Strategic Entrepreneurship Journal, 12(3), 354-368. https://doi.org/10.1002/sej.1300

Parker, G., \& Van Alstyne, M. (2012). A digital postal platform: definitions and a roadmap. America: The MIT Center of Digital Business.

Patton, M. Q. (2002). Qualitative evaluation and research methods (3rd ed.). CA: Sage Publications.

Perrons, R. K. (2009). The open kimono: how Intel balances trust and power to maintain platform leadership. Research Policy, 38(8), 1300-1312. https://doi.org/10.1016/j.respol.2009.06.009

Rieger, K. L. (2019). Discriminating among grounded theory approaches. Nursing Inquiry, 26(1), 1-12. https://doi.org/10.1111/nin.12261

Rietveld, J., \& Eggers, J. P. (2018). Demand heterogeneity in platform markets: Implications for complementors. Organization Science, 29(2), 304-322. https://doi.org/10.1287/orsc.2017.1183 
Rochet, J., \& Tirole, J. (2003). Platform competition in two-sided markets. Journal of European Economic Association, 1(4), 990-1029. https://doi.org/10.1162/154247603322493212

Sako, M. (2018). Technology strategy and management business ecosystems: how do they matter for innovation? Communications of the ACM, 61(4), 1-7. https://doi.org/10.1145/3185780

Täuscher, K., \& Laudien, S. M. (2018). Understanding platform business models: A mixed methods study of marketplaces. European Management Journal, 36(3), 319-329. https://doi.org/10.1016/j.emj.2017.06.005

Timonen, V., Foley, G., \& Conlon, C. (2018). Challenges when using grounded theory: a pragmatic introduction to doing GT research. International Journal of Qualitative Methods, 17(1), 1-10. https://doi.org/10.1177/1609406918758086

Tura, N., Kutvonen, A., \& Ritala, P. (2018). Platform design framework: conceptualisation and application. Technology Analysis \& Strategic Management, 30(8), 881-894. https://doi.org/10.1080/09537325.2017.1390220

Van Alstyne, M. W., Parker, G. G., \& Choudary, S. P. (2016). Pipelines, platforms, and the new rules of strategy. Harvard Business Review, 94(4), 54-62.

West, J., \& Wood, D. (2011). Tradeoffs of open innovation platform leadership: The rise and fall of Symbian Ltd. Stanford Social Science and Technology Seminar (pp. 1-46).

Wiesche, M., Jurisch, M. C., Yetton, P. W., \& Krcmar, H. (2017). Grounded theory methodology in information systems research. MIS Quarterly, 41(3), 685-701.

https://doi.org/10.25300/MISQ/2017/41.3.02 